\title{
BINDING OBLIGATIONS IN ROMANS 13:7: A SEMANTIC FIELD AND SOCIAL CONTEXT
}

\author{
Thomas M. Coleman
}

\begin{abstract}
Summary
Insufficient attention has been given to the meaning of the four distinctive terms

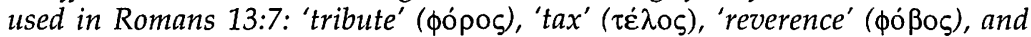
'honour' ( $\tau 1 \mu \eta$ ). This article will discuss these terms in relation to the GraecoRoman semantic field of political obligation, dividing them into the categories of 'tangible' obligations (tribute and tax) and 'intangible' obligations (reverence and honour). We vill also examine Romans 13:7 in light of the social context of the Neronean era, in which there was an increasing burden of taxation and the introduction of legal penalties for failure to show due reverence and honour to those in authority.
\end{abstract}

\section{Introduction}

Commentators have glossed over the significance of the four terms which Paul uses in Romans 13:7-terms which describe the obligations that Christians have toward civic authorities:

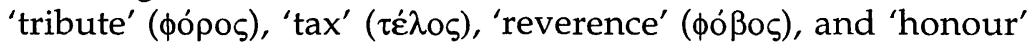
$(\tau \varkappa \mu \eta)$. For example, in his pre-war commentary on Romans, R.C.H. Lenski commented, in regard to Romans 13:7, that there was no unique significance in Paul's use of these terms. ${ }^{1}$ Lenski argued that the apostle's 'great positive principles... apply to all times, to us as well as to the Romans, to our relation to our secular government as well as to their relation to theirs'. ${ }^{2}$ C.E.B. Cranfield, likewise, discounted the particular relevance which Paul's words may have had for the Roman Christians, but for different reasons. Cranfield sought to find the source of Paul's

\footnotetext{
${ }^{1}$ R.C.H. Lenski, The Interpretation of St. Paul's Epistle to the Romans (Columbus: Lutheran Book Concern, 1936) 790.

Ibid., 789.
} 
sayings and located it in Gospel tradition ${ }^{3}$ and other New Testament documents ; the particular significance of the apostle's words to his Roman audience receives only secondary attention.

However, an important though neglected question to ask is: What was the import of these four terms, i.e. their meaning and the social context which they implied? This article will seek to examine both these issues.

\section{The Context}

Romans 13:7 is a part of a greater discussion of how the Roman Christians should deal with civil authorities. In the preceding verses (13:1-6) we find traditional Graeco-Roman thought on the government's dual role in society: It should punish the evildoer and reward those who do good. Greek and Roman writers alike-Lysias, Xenophon, Demosthenes, Diodorus Siculus, Josephus, Philo, Dio-all speak of the government's role in this way. ${ }^{5}$ As but one example, Philo says that the function of government is to mete out 'censure and chastisement according to law for wrong-doers (and) praise and honour for all welldoers, again, according to law'.6

In the immediate context of Romans 13:7, Paul places obedience to authorities in the moral realm; for the Christian, disregard of authority is a sin. This is because the authorities

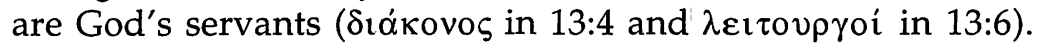
Christians have an obligation to give obedience to civil authority.

${ }^{3}$ C.E.B. Cranfield, The Epistle to the Romans (Edinburgh: T. \& T. Clark, 1979) II, 669-70.

${ }^{4}$ Ibid., 670-73. In his recent commentary, B. Byrne, Romans (Collegeville: The Liturgical Press, 1996), 389, 392, likewise commends this interpretation.

5See W.C. van Unnik, 'Lob und Strafe durch die Obrigkeit. Hellenistisches zu Röm 13,3-4', in E.E. Ellis (ed.), Jesus und Paulus: Festschrift fïr Werner Georg Kiimmel zum 70 Geburtstag (Göttingen: Vandenhoeck \& Ruprecht, 1975) 336-40, for other Graeco-Roman authors who discuss government's role.

6Philo, Mos., I.154. 
Thus, the use of obligation language in Romans 13:7 is significant.7 Paul's employment of such language made his exhortation in Romans 13:7 all the stronger. The same language that was used to describe payment of literal debts (loans, rents / leases, tribute, taxes, fines, and tithes) was also used to obligate people in their social relationships. Words such as $\dot{\alpha} \pi$ o $\delta i \delta \omega \mu \mathrm{t}$ and o $\phi \varepsilon i \lambda \omega$, used by Paul in Romans 13:7, alert us to this obligation concept and give greater weight to Paul's exhortations. Just as Christians were to pay off material debts, so also were they to meet their obligations to the state-both tangible and intangible. We turn now to discuss these four obligations.

\section{III. 'tribute' (фópos)}

Paul first addresses the tangible obligation of imperial subjects

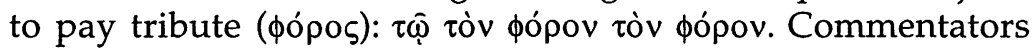
have historically suggested that $\phi o ́ p o \varsigma$ is a general reference to taxes of all kinds, and has nothing to do with the payment of

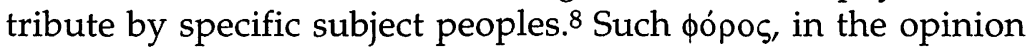
of most exegetes, does not have overtones of subjugation, this despite the fact that the literary evidence, as we shall see, points to a strong link between tribute and its payment by conquered peoples. Instead, commentators have usually believed that фópo $\zeta$ is merely a different type of tax, distinguished from the $\tau \dot{\varepsilon} \lambda$ o which Paul speaks of subsequently in that the former is a direct tax, while the latter is an indirect tax. ${ }^{9}$ Although he ultimately opts for the traditional interpretation, Morris does

\footnotetext{
${ }^{7}$ The language of obligation in the Graeco-Roman world finds its focalpoint in the word ó $\phi i \lambda \omega$ and its cognates. However, obligation language was certainly not limited to this; there was a whole semantic field, encompassing both synonyms and antonyms, which was used to convey the concept of obligation. (Consideration of the semantic field is a point often neglected by Biblical scholars.) In my doctoral dissertation, Loyalties Old and New: Binding Obligations in the Graeco-Roman World, Intertestamental Judaism, and Romans 12-15, I am seeking to explore these issues.

${ }^{8}$ See Lenski, Interpretation of Romans, 801; J. Murray, The Epistle to the Romans (Grand Rapids: Eerdmans, 1965) II, 156; and C.K. Barrett, The Epistle to the Romans (Peabody: Hendrickson, 1991) 228.

${ }^{9} \mathrm{H}$. Lietzmann, An die Römer (Tübingen: Mohr, 1933) 113.
} 
note that the фópos cited in Romans 13:7, with its connotations of vanquishment, is 'interesting'. ${ }^{10}$ As we shall seek to show in this section, we believe that Paul's use of фópos is much more than interesting. It has great significance, for it sheds light on the social context of the Roman Christians.

The фópos to which Paul refers in Romans 13:7 was

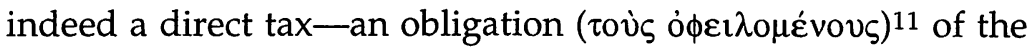
inhabitants of those lands which Rome had made part of its empire, either voluntarily or by force. In the form of land tax (tributum soli) and poll-tax (tributum capitis), this tribute was levied on those living in Roman provinces, be they Roman citizens or not, 12 for the imperial government 'neglected [no] source of provincial revenue which might have relieved the purses of Italians'.13 Exemption from this and all taxes Augustus considered the 'greatest privilege of all'; hence, it was very much sought after by cities, though seldom granted.14 Only those who lived in municipalities which were, firstly, Roman colonies, and, secondly, had been awarded the ius Italicum, were free of this obligation. ${ }^{15}$

But the significance of фópos does not lie merely in the fact that it was a direct tax. As noted above, its import-the overtones of subjugation-is also an important, but sorely neglected, point. That фópos did involve an aspect of subjugation is clearly witnessed in the writings of many Graeco-Roman authors. Though later, фópos came to denote rent paid for the lease of land,16 literary evidence from the New

\footnotetext{
${ }^{10} \mathrm{~L}$. Morris, The Epistle to the Romans (3rd. ed.; Grand Rapids: Eerdmans, 1988) 466.

${ }^{11}$ Diodorus Siculus, Hist., 27.15.2, 34/35.1.5; see also Philo, Spec. III.159.

${ }^{12}$ G.P. Burton, s.v. 'tributum', in S. Hornblower and A. Spawforth (eds.), The Oxford Classical Dictionary (Oxford: OUP, 1996) 1551.

13P.A. Brunt, 'The Revenues of Rome', in his Roman Imperial Themes (Oxford: Clarendon, 1990) 327.

${ }^{14}$ See J. Reynolds, Aphrodisias and Rome (Journal of Roman Studies Monographs 1; London: Society for the Promotion of Roman Studies, 1982) no. 13 l. 4.

15A.N. Sherwin-White, The Roman Citizenship (Oxford: Clarendon, 1973) 276, 320-22.

${ }^{16}$ See P.Tebt. 325 l. 15; 342 ll. 20, 21, 24; 368 l. 3; 377 ll. 14, 23, 27; 424 ll. 6-7; P.Oxy. $2712 l .8 ; 3268 l .12$.
} 
Testament era shows that, at this time, its meaning was much more restricted, even having a formulaic quality about it. Here, time and again in both Jewish and non-Jewish authors, we read of nations and cities that were conquered and forced to pay, quite begrudgingly, фópos. ${ }^{17}$

Of significance in regard to Romans 13:6-7 is the fact that, in numerous instances, Graeco-Roman authors use фópos in conjunction with $\tau \varepsilon \lambda \varepsilon \dot{\varepsilon} \omega$, employing, in an almost formulaic way, a form of the latter to indicate the payment of tribute by subject peoples. For instance, Diodorus, in his History, writes of Ninus, king of the Assyrians and conqueror of Babylonia.

(A)fter easily subduing the inhabitants of that region [Babylonia], because of their inexperience in the dangers of war, he laid upon them the payment of fixed yearly tributes

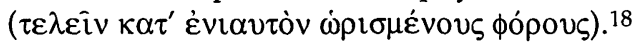

Josephus, as well, records how Agrippa, king of Judaea, urged

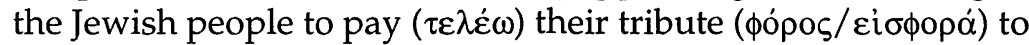
Caesar, thereby freeing themselves of the charge of insurrection. This the Jews did, paying this direct (communal)

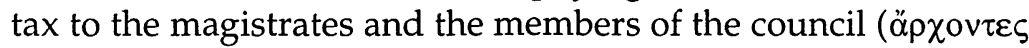

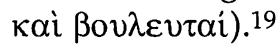

Because it was a tax aimed at subject peoples, the фópos was resented. Philo provides evidence of this when he compares the offering of tithes to Jewish priests, and the tribute paid by cities to conquering potentates. He explains that the former is

17Josephus, BJ., 2.402-406; Philo, Spec., I.142-43; 1 Macc. (LXX) 10.29; Diodorus Siculus, Hist., 1.18.5-6, 10.25.4, 11.47.1; Strabo, Geog., 4.5.3. On the basis of an extensive survey of the use of the term, only in Diodorus'

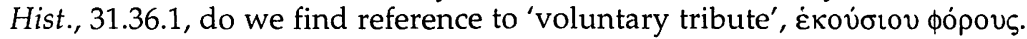
However, here $\tau \iota v a \varsigma$ precedes this, serving to indicate the irregularity of this occurrence. It was 'a sort of' tribute, paid by conquering kings to their subjects, the people of Rhodes. It was, in this instance, self-serving 'tribute', granted to the Rhodians because of their great willingness to flatter these rulers with public honours. In no way was this type of 'tribute' typical; фópos almost always denoted a direct tax which subject people were forced to pay to their conquerors.

18Diodorus Siculus, Hist. 2.1.7; see also 4.10.3, 13.114.1.

${ }^{19}$ Josephus, BJ ., 2.403-405. 
a complete contrast to the spirit in which the cities make

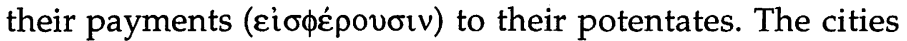
pay under compulsion and reluctantly and groan under their burden. They look askance at the tax-collectors as general agents of destruction. ${ }^{20}$

It would seem that these collectors were indeed 'agents of destruction', for, as we read elsewhere, they were willing to torture and even kill family and immediate kin of those who failed to pay what was owed.21

Thus, we see that an important aspect of фópo $\varsigma$ was that it connoted subjugation. But, one might ask, how does this relate to the Roman Christians, since the inhabitants of the city of Rome were not liable for direct taxation? In answer to this question, we propose that Paul is dealing with, at least in part, a situation during the reign of Nero in which Jews have returned from the provinces after having been expelled from the city by Nero's predecessor, Claudius. During Nero's reign, there was introduced in Roman Egypt the concept of idia, which sought to prevent flight from the burden of taxation by creating a stronger bond between the individual and the community in which he fulfilled his obligations to the state. If Egypt was typical of the eastern provinces 22 and the idia introduced into the administration of all eastern lands, the Jews returning to Rome would have been liable for the payment of direct tax in the provinces in which they had resided during the previous census, taken in A.D. 54/5.23

20Philo, Spec., I.143.

21 Ibid., III.159-60.

22This point is admittedly debatable. Though some scholars hold that the situation in Egypt was almost entirely unique, others believe this not to be the case. N. Lewis, for instance, argues 'that the more our studies bring to the fore the Roman elements in the organisation of Roman Egypt (including the law), the less unique Egypt appears and the more it represents other eastern provinces of the Roman Empire' (cited in B. Winter, 'The Importance of the Captatio Benevolentiae in the Speeches of Tertullus and Paul in Acts 24:1-21', JTS 42.3 [1991] 507, n. 11).

23S.L. Llewelyn, Nezv Documents Illustrating Early Christianity (Macquarie: The Ancient History Documentary Research Centre, 1992) VI, 113, 125-26. The idin required that a person pay tax in the community in which he was registered at the taking of the previous census. 
Thus, Jews moving to Rome from the provinces, such as Priscilla and Aquilla, may have resented the fact that they, though inhabitants of the capital city, were still treated as subject people, having to pay tribute just as all provincials did. Likewise, sojourning Gentiles would have been liable for provincial taxes, and, assuming, as is surely the case, that they made up a significant part of the Roman Christian population, may also have been discontent over this situation. Only those who were Roman citizens would have been free from this burden. To the others, Paul urges obedience. Using the formula common in literature of the period ( $\tau \varepsilon \lambda \varepsilon i \tau \varepsilon$ pópovৎ in v. 6), he commands that they fulfil their obligation to the state, paying tribute to whom tribute is due.

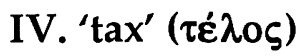

The second tangible obligation to which Paul exhorts the

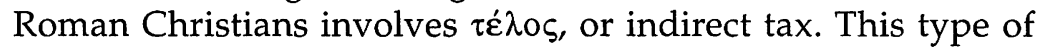
tax was levied on goods and services. ${ }^{24}$ Everything that was traded, whether nails, ${ }^{25}$ grain, ${ }^{26}$ animals, ${ }^{27}$ or even sex, ${ }^{28}$ was liable to be taxed, no matter where the business took place; unlike tribute, Roman citizens enjoyed no privileged exemption from payment of $\tau \dot{\lambda} \lambda \circ \varsigma$.

Papyri are most helpful in discovering information about the Roman system of indirect taxation. These show that the Roman population paid $\tau \dot{\varepsilon} \lambda$ os on sales of: land, ${ }^{29}$ houses, ${ }^{30}$ oil, ${ }^{31}$ and grass, ${ }^{32}$ among other things. Also subject to $\tau \dot{\lambda} \lambda$ o was the right to participate in various trades, such as the dyer's

${ }^{24}$ Murray, Romans, 156; Barrett, Romans, 228.

${ }^{25}$ Brunt, 'Revenues of Rome', 329.

26Llewelyn, New Docs., VI, 113.

27Llewelyn, Newo Docs., VI, 113.

${ }^{28}$ Brunt, 'Revenues of Rome', 329.

29P.Tebt. 280 l. 5-6.

30P.Tebt. 350 l. 9; 351 l. 3, 7.

31 P.Tebt. 38 l. 10.

32P.Tebt. 379 l. 17. 
trade ${ }^{33}$ and the weaver's trade. ${ }^{34}$ One sees the extent to which the Roman taxation system intruded in the lives of the populace in the case of the individual who was even taxed on the right to collect (a fishery) tax! ${ }^{35}$

Just how lucrative this taxation scheme was is revealed in Strabo's discussion of Roman Britain. Here the historian

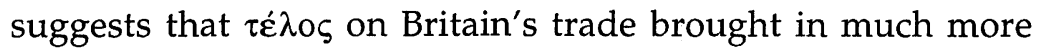
revenue than фópos could.

(N)o corresponding advantage was to be gained by taking and holding their country [Britain]. For it seems that at present more revenue is derived from tax ( $\tau \dot{\lambda} \lambda \circ \varsigma)$ on their trade than the tribute (фópos) could bring in, if we deduct the expense involved in the maintenance of an army for the purpose of guarding the island and collecting the tribute. ${ }^{36}$

Here Strabo provides a helpful contrast between $\tau \varepsilon \dot{\lambda} \mathrm{s}_{\zeta}$ and фópos. Not only does he show that tribute suggests subjugation, but he also reveals that indirect taxation could be as, if not more, lucrative for the empire than direct taxation.

It should come as no surprise, then, that Paul chose to address both types of taxation, direct and indirect, for the Roman system of taxation reached into every facet of the lives of the citizens of the Empire, whether they resided in the provinces, in Italy, or even in the capital city itself. Moreover, Byrne has noted how civil unrest

had come to a head in the late 50's centering upon abuses in the collection of taxes. Things came to such a pitch in 58 C.E. that Nero seriously considered abolishing indirect taxes altogether but was persuaded by advisers to institute reforms designed to curb abuses. ${ }^{37}$

${ }^{33}$ P.Tebt. 287 ll. 3-4, 10.

${ }^{34}$ P.Tebt. 384 l. 20.

35 P.Tebt. 329.

36Strabo, Geog, 2.5 .8 .

37Byrne, Romans, 386. We will discuss the significance of this occurrence in the final section of this article. 
Paul exhorts the Roman Christians not to contribute to this civil upheaval, but be good citizens, showing their obedience to the authorities by paying tax to whom tax is due.

\section{V. 'reverence' (фóßo૬)}

Just as the first two terms were linked, both being tangible obligations due to the state, so the latter two terms are related in that they are both intangible obligations. Scholarly consensus has held that the 'the former ( $\phi$ ó $\beta$ os) has in view the respect paid to those on the highest level of authority and the latter ( $\left.\tau \mu \eta^{\prime}\right)$ that paid to those of lower rank.'38 However, evidence cannot be cited to support this contention.

The first term, фóßos, has troubled exegetes. Typical is Lenski, who argues for what amounts to no more than a contradiction in Paul's thought. ${ }^{39}$ Though Paul speaks of $\phi o ́ \beta o s$ as an obligation which is to be acknowledged and met by Christians, Lenski believes that this is not a necessary фóßos, but one which manifests itself only in those Christians who insist

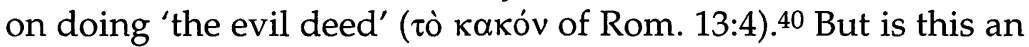
'optional' фóßos? Romans 13:7 suggests it is not, given the binding nature of obligation in the Graeco-Roman worldobligation which Paul refers to through his use of the actual word ó $\phi \varepsilon i \lambda \omega$ in this verse. Just as it was clear that the Christians had an obligation to pay tribute and taxes, so it was their obligation to give фó $\beta$ os to whom фóßos is due.

But who or what was the object of this фó $\beta$ s? Given the immediate context, where we find numerous occurrences of both $\phi o ́ \beta o s$ and its verbal cognate $\phi о \beta \varepsilon \dot{\varepsilon} \omega$, it seems quite natural

\footnotetext{
${ }^{38}$ Murray (Romans, 156) does believe, however, that there is not sufficient evidence to make this an indisputable conclusion. Cranfield (Romans, 670) notes also that it is the general opinion of scholars that $\phi$ ó $\beta$ o $\zeta$ denotes a greater, and $\tau \iota \dot{\eta}$, a lesser, degree of respect.

${ }^{39}$ Lenski, Interpretation of Romans, 801.

40Byrne (Romans, 392) as well, arguing that God rather than men should be

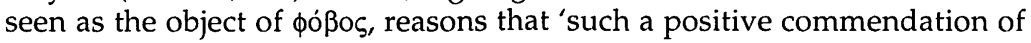
"fear" [as found in v. 7] would clash with the way in which "fear" of earthly rulers is presented in vv 3-4; as something negative, applicable only to wrongdoers.'
} 
to assume that Paul has in mind the same parties throughout,

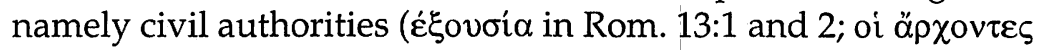
in 13:3). It is true, as most exegetes of this passage note, that in the New Testament, with the exception of Ephesians 5.33,41 God or Christ is always the object of $\phi o ́ \beta o s$, and not humans. However, in Romans 13:1-7 we are not dealing with worship, but with obligation to civic authorities. 42 Therefore the meaning should be sought in the semantic field of politics and not religion.

An obvious but oddly neglected lexical point is that, according to Liddell and Scott, фóßos can also denote 'reverence', particularly to civil authorities. Balz, writing in the $T D N T$, notes many papyri, dated from the third century to the sixth century A.D., where $\phi$ ó $\beta$ os refers to the respect which should be shown to civil authorities. 43 We should also note the very important example found in an early fourth-century A.D. official court proceeding, concerning a property dispute brought before a civil magistrate in Oxyrhynchus. This local official had been sent an order by the prefect of Egypt to resolve this matter. He readily complies with the wishes of the prefect, 'keeping in my heart the фóßos of the nobility of so great an official'. 44 Relevant too is the Pseudo-Aristotelian document, of uncertain date and now only existing in Latin translation, which speaks of two kinds of timor:

the timor which virtuous and honourable sons feel towards their fathers, and loyal citizens towards right-minded rulers... the other kind, felt by slaves for masters and by subjects for despots who treat them with injustice and wrong 45

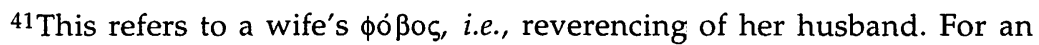
epigraphic example of the same, see SEG 35.1427, l. 5 (3rd cent. A.D.), cited in Liddell and Scott, Revised Supplement (Oxford: Clarendon, 1996).

${ }^{42}$ Contra Cranfield (Romans, 671-72) who believes, as mentioned prior, that $\phi o ́ ß o \zeta$ in Rom. 13:7 is in reference to God.

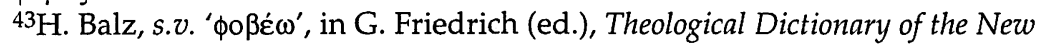
Testament (Grand Rapids: Eerdmans, 1974) 194.

44P.Oxy. 3757, l. 9 .

45Pseudo-Aristotle, Oec. III, 3. In his introduction on pp. 324-25, G. Cyril Armstrong states that this third book of Oeconomica was translated from 
Thus, $\phi{ }^{\prime} \beta o \varsigma$, and its Latin equivalent timor, can connote 'reverence' or 'respect'.

There are other documents, as well, in this case Jewish, in which фóßos connotes respect of human authority. In the LXX version of Leviticus 19.3, which reflects third-century B.C. Greek usage of this term, the command is given to the people of Israel: 'Each of you respect ( $\phi \circ \beta \varepsilon \dot{\varepsilon} \omega)$ your father and mother.' 46

More importantly, in the LXX version of Numbers 12.8 (a passage interesting especially because of its relevance to Rom. 13:7) Yahweh is said to have spoken of Moses as his 'servant' $(\theta \varepsilon \rho \alpha ́ \pi \omega v)$ who should be respected ( $\phi \circ \beta \varepsilon \dot{\varepsilon} \omega)$. Here, as in the immediate context of Romans 13:7, a human authority, Moses, is described as God's servant ( $\theta \varepsilon \rho \alpha \dot{\pi} \omega \omega)$. Likewise, twice in Romans 13:4 the civil authorities in Rome are said to be,

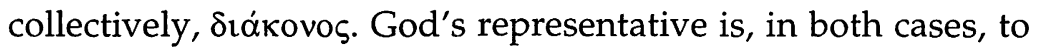
be held in respect, for he is an authority appointed by God. 47

There is therefore no conflict in Paul's thought in regard to the фóßos spoken of throughout Romans 13:1-7. He is rather emphasising two different aspects of civil authority: For the one

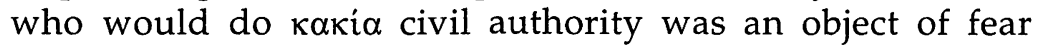
( $\phi$ ó $\beta$ os), for it was there to punish. As we noted in a previous section, this is the traditional Graeco-Roman belief about the role of government. But all were to give the civil authorities 'respect' (фóßos).

Having seen how $\phi o ́ \beta 0 \varsigma$ can denote 'respect' in the semantic field of politeia, we now need to address the issue of exactly who were these authorities whom Paul commands the Roman Christians to respect. As we have seen in the evidence

Greek into Latin in 1295 by Guillaume Durand, a Bishop of Mende who died in Rome in 1296.

46Pr. 24.21 states that God and the king should be feared ( $\phi \circ \beta \varepsilon \omega)$. However, the following verse speaks of the destruction which each of these can wreak, thus implying that the фó $\beta$ os to which the readers are exhorted is fear of wrath, and not respect for authority. A. Strobel ('Furcht, wem Furcht gebührt: Zum profangriechischen Hindergrund von Rm. 13.7', ZNW 55 [1964], 5) sees Pr. 24:21 (mistakenly cited as Pr. 24.17) as reflecting the same idea as Rom. 13:7.

47 In Nu. 12:7-8, Moses, who alone is allowed to see the glory of the Lord and with whom God speaks mouth to mouth, is also described as faithful $(\pi$ rotis) in God's whole house. 
cited in this section, kings and prefects were spoken of as deserving reverence. By way of analogy, in Rome the emperor and his vicegerents merited reverence, as well as those who undertook honorary liturgies ( $\lambda \varepsilon \imath \tau o v \rho \gamma i \alpha \imath)$, serving as civil magistrates, etc. ${ }^{48}$ In his counsel to respect those deserving of respect in Romans 13:7, the apostle exhorts all Christians to recognise their binding obligation to acknowledge these authorities-the emperor, his officials, civil magistrates/ liturgists, etc.

\section{VI. 'honour' ( $\left.\tau \mu \mu \dot{\eta}^{\prime}\right)$}

Regarding the fourth term, $\tau \iota \mu$ ' we have here Paul's reference to a second intangible obligation, 'honour'. Traditionally, commentators have viewed this as encouraging something very much akin, though less than, the фó ßos in the prior phrase, the object of this honour being those in authority. Alternatively, Stulmacher argues that this honour might be directed toward God (harking back to the logion of Jesus found in Lk. 20:25) or that it could be honour which Christians owe to all people (echoing 1 Pet. 2:17), not just those in authority. ${ }^{49}$ However, we shall argue in this section that this term carried different and quite distinctive import, thus far unexplored in connection with this verse.

The great social significance of $\tau \imath \mu \eta$ is emphasised in J.E. Lendon's observation that honour

was a filter though which the whole world was viewed, a deep structure of the Graeco-Roman mind, perhaps the ruling metaphor of ancient society... Every thing, every person, could be valued in terms of honour, and every group of persons. 50

48J.E. Lendon, Empire of Honour: The Art of Government in the Roman World (Oxford: Clarendon, 1997) 34.

49P. Stulmacher, Paul's Letter to the Romans: A Commentary (Edinburgh: T. \& T. Clark, 1994) 204.

50Lendon, Empire of Honour, 73. 
For example, honour was what great men expected to receive from their inferiors. It was the appropriate response not only to esteemed civic qualities, ${ }^{51}$ summarised in virtue ( $\left.\dot{\alpha} \rho \varepsilon \tau \eta \dot{)}\right)$, but also to civic actions, very often, public benefactions. ${ }^{52}$ Because they already possessed honour, good men (oi $\dot{\alpha} \gamma \alpha \theta$ oí$^{\prime}$-another way of designating civic benefactors-did deeds which augmented their honour. ${ }^{53}$ Thus does Saller note that ' $t$ the most basic premise from which the Romans started was that honor and prestige derived from the power to give what others needed or wanted'.54

Linked closely with the giving of benefactions is the idea of reciprocity, i.e., an appropriate response. In De Beneficiis, Seneca acknowledges the need for reciprocity, even viewing it as an obligation-a debt which must never be forgotten, but repaid. ${ }^{55} \mathrm{He}$ explains that his readers

need to be taught to give willingly, to receive willingly, to return willingly, and to set before us the high aim of striving, not merely to equal, but to surpass in deed and spirit those who have placed us under obligation, for he who has a debt of gratitude (gratia) to pay never catches up with the favour unless he outstrips it. 56

On the Jewish side, Philo instructs his readers likewise:

51 Ibid., 44.

52 Within this category of 'benefactions' we include liturgies.

${ }^{53} \mathrm{~A}$ civic benefactor was often called a 'good man' (bonus vir) who does 'good'-in Greek, $\dot{\alpha} \gamma \alpha \theta$ oroı́s, and in Latin, beneficium. Thus, patronage was, in both Latin and Greek, linked with the 'good' ( $\alpha$ ' $\alpha \theta 0 \varsigma$, bene, bonus). See A.D. Clarke, 'The Good and the Just in Romans 5:7', TynB 41 (1990) 128-42.

${ }^{54}$ R.P. Saller, Personal Patronage under the Roman Empire (CUP, 1982) 126. See also A.D. Clarke, Secular and Christian Leadership in Corinth: A Sociohistorical and Exegetical Study of 1 Corinthians 1-6 (Leiden: Brill, 1993) 30-31. ${ }^{55}$ The language of obligation is very common throughout De Beneficiis; see especially 4.40 .5 .

${ }^{56}$ Seneca, Bene., 1.4.3. Elsewhere Seneca states that 'I am able to place a man under obligation only if he accepts; I am able to be freed from obligation only if I make return' (7.18.2). And again, '[A]lthough we say that he who receives a benefit gladly has repaid it, we, nevertheless, also bid him return some gift similar to the one he received'. (2.35.1) Pliny, Letters, 7.31, called reciprocity the code of friendship. 
it is necessary that we learn to pay heed to benefactors

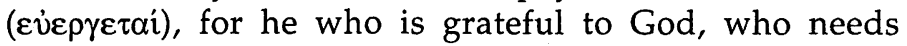
nothing and is in his own fullness, will thus become accustomed to be grateful to men, who have a myriad of needs. 57

The recipient of a benefaction was obliged to make a return. 58 Failure to do so was considered an even greater sin than an unwillingness to give in the first place. 59

The reality was, however, that very often no tangible return could be made. ${ }^{60}$ Especially with humble people, when in the public sphere true (tangible) reciprocity was not an option, intangible $\tau \iota \mu$ ' was the way to meet the demand for a return. ${ }^{61}$ Such people had to do whatever they could, no matter how insignificant, to show honour to those who benefited them. 62

Thus, Seneca, in De Beneficiis, discusses the two classes of grateful beneficiaries. ${ }^{63}$ For one, reciprocity involved tangible returns64_public acknowledgement or 'praise', with 'the Council and the People' awarding inscriptions, statues, crowns of gold, and seats of honour in the theatre. It was these that constituted the 'culminating feature of grateful response in the Graeco-Roman world'.65 For the other, reciprocity meant

57Philo, Spec. , II.174.

58Saller, Personal Patronage, 14.

59Seneca, Bene., 1.1.13.

${ }^{60}$ Lendon, Empire of Honour, 67.

${ }^{61}$ For an excellent short summary of the reciprocity involved in beneficiary relations, see S.C. Mott, 'The Power of Giving and Receiving: Reciprocity in Hellenistic Benevolence', in G.F. Hawthorne (ed.), Current Issues in Biblical and Patristic Interpretation, (Grand Rapids: Eerdmans, 1975) 60-72.

62Lendon, Empire of Honour, 68.

63Seneca, Bene., 4.21.1-2.

${ }^{64}$ Ibid., 4.21.1-2; see also Plutarch, Moralia, 95E.

65F.W. Danker, Benefactor: Epigraphic Study of a Graeco-Roman and New Testament Semantic Field (St. Louis: Clayton Publishing House, 1982) 467. Danker (467-68) cites 13 such returns ordinarily given to civic benefactors: a crown or wreath, a statue, a shield with a portrait engraved thereon, chief seating at public events, equality in taxation, exemption from taxation, the right to wear the purple robe of honour for life, inviolability of person or property, public maintenance, citizenship, immunity from the 
accepting a benefit in good spirit: gratefully acknowledging that it had been received, proclaiming it, and admitting to others one's inability to repay it. ${ }^{66}$ One who had such an attitude of gratia knew how to express his indebtedness. Though he may not have been able to repay, he had the proper state of mind-that which desired to repay-and this gave evidence of his grateful heart.67 Hence an attitude of gratia constituted acceptable repayment.

Throughout the literature and inscriptions of the day, we find evidence of the obligation to give honour to the great and powerful, in the form of tangible or intangible returns. In the Roman world, the one who wielded the greatest power was, of course, the emperor. Philo encourages the giving of appropriate honour to this, the greatest of all benefactors, arguing that 'the emperors are superior to the Ptolemies in prestige and fortune and ought (oj $\phi \varepsilon i \lambda \omega)$ to gain superior honours $\left(\tau \mu \alpha \alpha^{\prime}\right)^{\prime} .68$ Elsewhere in the same discourse, Philo notes

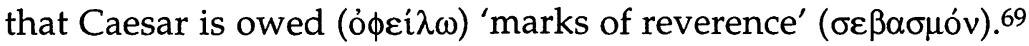
Also, Dio Chrysostom speaks of the obligation owed to the emperor by the people of Tarsus:

what you obtained from that one (Caesar) formerly through your goodwill ( $\varepsilon$ v้vor $\alpha$ ) and friendship ( $\phi \lambda \lambda i \alpha)$, this you are obligated (o $\phi \varepsilon i \lambda \omega)$ to safeguard for the future through discipline $(\varepsilon \dot{v} \tau \alpha \xi i \alpha)$ and through giving no occasion for criticism. 70

Having received benefactions through their 'friendship' with Caesar, they were, consequently, bound to safeguard their good standing with the emperor through (1) 'discipline', which certainly entailed giving appropriate honour, and (2) 'giving no occasion for criticism'. By doing so, the people of this Cilician city would merit additional benefactions and enjoy high regard

expense of public services (liturgies), the status of proxenos (public friend of a foreign political entity), and annual honours.

66Seneca, Bene., $1.1 .3 ; 2.24 .4 ; 2.30 .2 ; 2.33 .1 ; 2.35 .5 ; 4.21 .2$.

67Ibid., 5.4.1-2.

68Philo, Legat., 10.140.

${ }^{69}$ Ibid., 10.152

70Dio Chrysostom, Or., 34.25. 
in the eyes of Caesar and the Roman authorities. In the words of the Emperor Claudius, addressed to the Alexandrians, the goodwill of the emperor, which was witnessed in his bestowing benefactions upon a city, inspired the goodwill ( $\varepsilon$ vovor $\alpha$ ) of the city, which was witnessed in its giving appropriate honours

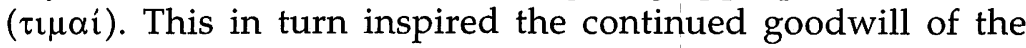
emperor. 71

Just as there was an obligation to honour the emperor, so also was there an obligation to honour lesser officials for their beneficent rule. Plutarch explains that honour comes

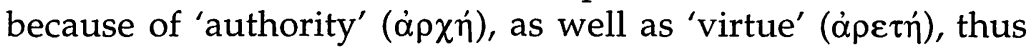
highlighting the close relationship between civic leadership and the giving of benefactions. ${ }^{72} \mathrm{He}$ also assumes elsewhere that an

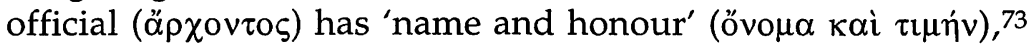
and he gives his assent to the belief that

those who do good should always benefit from their beneficiaries, through recompense and a debt of gratitude

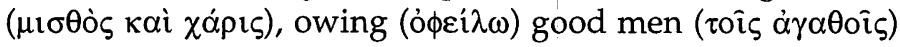
honour ( $\left.\tau \mu \eta^{\prime}\right)$ (and) always esteeming according to the good (they do). ${ }^{74}$

The turn-of-the-era historian and geographer Strabo enumerates some of these honours: a front seat ( $\pi \rho \circ \delta \delta \rho i \alpha)$ at public events, a purple robe, and superintendance at religious sacrifices. 75

Turning to inscriptions, we find some of these same ideas about $\tau \iota \mu \eta$, as well as the belief that honours begot honours. In an inscription set up by the city council of Dionysopolis, the city's benefactors receive $\tau \mu \mu$,' 'so that it may be seen that the people [of Dionysopolis] honour "good and

71 P.Lond. 1912 ll. 21-2.

72Plutarch, Moralia, 617C. Plutarch also comments that ties of kinship

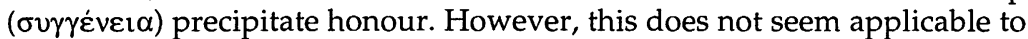
what Paul says in Rom. 13, dealing as he does with the powers that be in Rome.

73Plutarch, Cat., 16.7.3. Philo, Spec., I.142, also speaks of the honours owed to royalty, as does Strabo, Geog., 13.1.52.

${ }^{74}$ Plutarch, Phil., 21.12.6.

75Strabo, Geog., 14.1.3. 


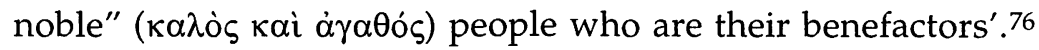
So too did the city council of Julia Gordos, in a first-century C.E. inscription, command that Theopholis be honoured 'so that all may know that such people who exercise their life on behalf of their country gain a testimony'. ${ }^{77}$ Likewise, it was the concern of the city council of Sestos that its benefactors, whether actual or potential, know that their city had been faithful in giving

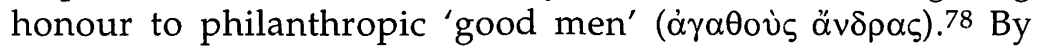
advertising its giving of honours, a city expected to acquire more benefits, as this same inscription from Sestos indicates, honouring Menas

in order that all might know that Sestos is hospitable to men of exceptional character and ability... and that the people might not appear remiss in their gratitude, and that also all others, as they see the people bestowing honour $(\tau \imath \mu \dot{\eta})$ on exceptional men, might emulate the noblest qualities and be moved to virtue, to the end that the common good might be advanced as all aim ever to win a reputation for doing something beneficial for our home city. ${ }^{79}$

Benefactions given and gratefully received were expected to compel the giving of more benefits. 80

Though honour, in whatever form it took, was the expectation of beneficiaries and the obligation of beneficiaries, it is obvious that in some cases it was not the reality. Dio himself experienced trouble in regard to benefactions which he intended to bestow on his native city, his opponents persuading

\footnotetext{
76For the Greek text, see no. 662, $l l .42-44$, in R. Cagnate (ed.), Inscriptiones Graecae ad res Romanas pertinentes (Paris: Leroux, 1911) I, 220.

${ }^{77}$ No. 18 in G.H.R. Horsley (ed.), New Documents Illustrating Early Christianity (Sydney: Macquarie University Ancient History Documentary Research Centre, 1982) II, 58-59.

${ }^{78}$ See 1.60 of the Greek text published in C. Curtius, 'Inschrift aus Sestos', Hermes 7 (1873) 114-21.

${ }^{79}$ No. 17 in Danker, Benefactor, 92-97. (See $1 l$. 86-93. The translation is largely Danker's, but slightly modified.) This same advertisement motif is found in an inscription in which the city of Lasos praised Herokrates. See no. 16 in Danker, Benefactor, 89-91, and, for the Greek text, F. Frhr. Hiller von Gaertringen (ed.), Inschriften von Priene (Berlin: Reimer, 1906) no. 53.

80See also Seneca, Bene., 4.15.3.
} 
those who promised to provide additional support for his project to withdraw it. 81

Also a problem was the failure to honour one's beneficiary, which constituted gross ingratitude, and this the whole world counted a disgrace. 82 It could even be regarded as criminal. ${ }^{83}$ Dio speaks of the gravity of this offence:

there is nothing more weighty, no debt owing (ó $\phi \varepsilon i \lambda \omega)$

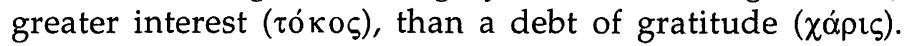

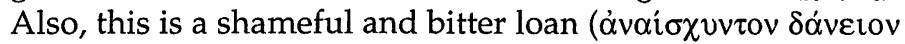

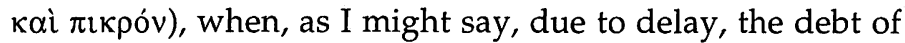
gratitude ( $\chi \dot{\alpha} \rho ı)$ ) is replaced by a debt of duty ( $\left.\chi \rho \varepsilon \varepsilon^{\prime} \varsigma\right)$, the settlement of which those who keep silent demand all the more harshly than those who cry out. For nothing has such power to remind those owing (óфci $\lambda \omega$ ) you something as to forget you. ${ }^{84}$

Important in this passage is the fact that here, as in Romans 13:6-7, obligation language is used to refer to both literal and metaphorical debts. Dio elaborates and strengthens the idea that a benefactor is 'owed (ó $\phi \varepsilon i \lambda \omega$ ) thanks', 85 contending that a metaphorical debt to show gratitude to one's benefactor (and thus honour him) accrues even greater interest than a financial debt. 86 However, unlike the financial debt, those who are owed a metaphorical debt of gratitude do not 'cry out', demanding repayment as money lenders so often did. All the same, if this obligation to show gratitude was not met, it became a debt of

\footnotetext{
81See Dio Chrysostom, Or., 40.6 and 45.13. For a discussion of this, see B.F. Harris, 'Bythinia: Roman Sovereignty and the Survival of Hellenism', ANRW II.7.1 (1980) 892; as well as C.P. Jones, 'Benefactions', The Roman World of Dio Chrysostom (Cambridge: Harvard UP, 1978) ch. 12.

${ }^{82}$ Seneca, Bene., 3.1.1.

83Ibid., 3.6.2.

${ }^{84}$ Dio Chrysostom, Or., 40.3-4.

${ }^{85}$ At 44.4 and 45.10 , Dio mentions this. In the former of these, Dio, in typical rhetorical style, speaks of himself, a benefactor, owing thanks to his native city of Prusa for the honours given to his ancestors. He states that he hopes 'to repay' ( $\dot{\alpha} \pi 0 \tau i v \omega$ ) them for this-probably an acknowledgement that he too, as his ancestors before him, would reward them with more benefactions.

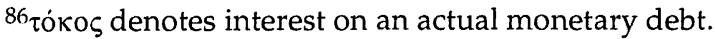


duty which demanded to be repaid, as shameful and bitter a loan as any financial debt ever was. 87

Paul teaches that the Christians were to respect not only the office of those in leadership ( $\phi$ ó $\beta \circ \varsigma$ ), but they were also to honour these individuals for their actions ( $\tau \mu \eta \dot{)})$, namely the giving of liturgies ( $\lambda \varepsilon \varepsilon \tau o v \rho \gamma i \alpha \imath$ ), which was so often a part of Roman civil service. They were to do this because these officials were God's servants ( $\lambda \varepsilon \imath$ เovprioi $\theta \varepsilon \circ \hat{v})$ (Rom. 13:6).

\section{Sitz im Leben}

It is our contention that Paul's letter to the Romans was written during a time of increasing dissatisfaction over the burden of taxation in the Neronean Principate (A.D. 54-68), contrary to the general consensus among scholars that the background of Romans 13:1-7 has its genesis primarily in the reign of Claudius (A.D. 41-54). For example, Friedrich, Pöhlmann, and Stulmacher saw a nexus between the tax protests of A.D. 58, and the disturbances over 'Chrestus' in A.D. 49 which resulted in the eviction of Jews from Rome. This, they contended, was the reason that Paul wrote as he did in Romans 13:1-7, encouraging all Christians, in light of the former Jewish exile from Rome, to avoid drawing attention to themselves and to fulfil their obligations to pay taxes. 88

Strobel, on the other hand, finds the historical background for Romans in Claudius' decree of A.D. 53, in which procurators were granted special powers. He suggests that these powers perhaps even included those of levelling taxes, though in the quotation which he cites, Tacitus makes no mention of the matter of taxation. 89 We find no evidence during Claudius' reign of dissatisfaction over the burden of taxation,

\footnotetext{
${ }^{87} \delta \dot{\alpha} v \varepsilon ı$ ov also signifies a literal debt-money lent, often at usurious rates of interest.

88J. Friedrich, W. Pöhlmann, P. Stulmacher, 'Zur historischen Situation und Intention von Röm 13,1-7', ZTK 73 (1976) 131-66.

${ }^{89}$ Tacitus, Ann., 12.60. See Strobel's discussion of this in 'Furcht, wem Furcht gebhürt', 61-62.
} 
for, as B. Levick has noted, the taxes imposed by Gaius were abolished by Claudius early in his reign. ${ }^{90}$

Contrary to the views expressed in these two articles, we believe it to be more probable that Romans 13:1-7 reflects popular dissatisfaction over taxation during Nero's reign. At this time, and not earlier, did the monetary demands of indirect taxes become particularly oppressive, as Tacitus affirms. He records that the emperor Nero almost capitulated to the 'repeated demands from the public' for relief from the burden of $\tau \varepsilon \lambda$ ós. However, he writes that

Nero hesitated whether he ought not to decree the abolition of all indirect taxation and present the reform as the noblest of gifts to the human race. His impulse, however, was checked by his older advisers, who pointed out that the dissolution of the empire was certain if the revenues on which the state subsisted were to be curtailed: 'For, the moment the duties on imports were removed, the logical sequel would be a demand for the abrogation of the direct taxes. ${ }^{\prime 91}$

Nero not only increased indirect taxes, but also direct ones. Suetonius notes that, even towards the end of his life, Nero continued to increase the tax burden. At that time, in order to raise badly needed funds for a war effort, he required all tenants to pay a de facto tax of a year's rent to the imperial purse. He also mandated that all classes pay a direct (income) tax.92 It seems that at this time not even Roman citizens escaped the burden of direct tax. Those who attempted to do so were punished, for tax evasion was a criminal offence. ${ }^{93}$

Besides tangible obligations, intangible obligations, as well, were of concern to the Julio-Claudian emperors. Failure to give due reverence and honour for benefactions attracted legal penalties. Claudius, for instance, 'reduced to slavery again any

\footnotetext{
${ }^{90}$ B. Levick, Claudius (London: Batsford, 1990) 132, and Dio Cassius, Roman History, 60.4.1.

91Tacitus, Ann., 13.50. See also Suetonius, Nero, 44.1

92Suetonius, Nero, 44.2.

93 O.F. Robinson, The Criminal Law of Ancient Rome (London: Duckworth, 1995) 90-91.
} 
such (freedmen) as were ungrateful and a cause of complaint to their patrons (i.e., their former masters)' ${ }^{\prime}{ }^{94}$ Nero went even further, making into law a practice which Gaius had initiated and Claudius had continued: punishment of the ungrateful. 95 Nero legislated that the estates of the 'ungrateful' - those who failed to make monetary provision for him in their willswould be confiscated. 96

In light of the above discussion, it is no surprise that Paul would write to the Christians in Rome, exhorting them, for 'for conscience sake' (v. 5, in regard to a breach of the law, which is 'the evil deed', v. 4), to fulfil both their tangible obligations to the state in regard to tribute and taxes, as well as their intangible obligations to give reverence and honour to those in authority. The exhortation in Romans 13:7 provides a summary for Paul's discussion of Christian and secular authorities, ${ }^{97}$ stressing four obligations-which are but one part of a wider sphere of binding commitments discussed by Paul in Romans 12-15-that bound the Roman Christians to obedience in the social/political realm of their existence. ${ }^{98}$

\footnotetext{
94Suetonius, Claudius, 25.1; see also A. Watson, Roman Slave Law (Baltimore: Johns Hopkins UP, 1987) 39-40.

95M.T. Griffin, Nero: The End of a Dynasty (London: Batsford, 1984) 204-05.

${ }^{96}$ Suetonius, Nero, 32.2.

97Stulmacher, Romans, 199.

${ }^{98} \mathrm{I}$ would like to thank Dr. Bruce W. Winter for his advice on several aspects of this article.
} 